\title{
In vitro assessment of safety and probiotic potential characteristics of Lactobacillus strains isolated from water buffalo mozzarella cheese
}

\author{
Sabrina Neves Casarotti ${ }^{1,2} \cdot$ Bruno Moreira Carneiro $^{3} \cdot$ Svetoslav Dimitrov Todorov $^{4}$. \\ Luis Augusto Nero ${ }^{4}$ Paula Rahal ${ }^{5}$ - Ana Lúcia Barretto Penna ${ }^{1}$
}

Received: 10 August 2016 / Accepted: 7 February 2017 /Published online: 28 February 2017

(C) Springer-Verlag Berlin Heidelberg and the University of Milan 2017

\begin{abstract}
The aim of this study was to evaluate the safety and probiotic potential characteristics of ten Lactobacillus spp. strains (Lactobacillus fermentum SJRP30, Lactobacillus casei SJRP37, SJRP66, SJRP141, SJRP145, SJRP146, and SJRP169, and Lactobacillus delbrueckii subsp. bulgaricus SJRP50, SJRP76, and SJRP149) that had previously been isolated from water buffalo mozzarella cheese. The safety of the strains was analyzed based on mucin degradation, hemolytic activity, resistance to antibiotics and the presence of genes encoding virulence factors. The in vitro tests concerning probiotic potential included survival under simulated gastrointestinal (GI) tract conditions, intestinal epithelial cell adhesion, the presence of genes encoding adhesion, aggregation and colonization factors, antimicrobial activity, and the production of the $\beta$-galactosidase enzyme. Although all strains
\end{abstract}

Sabrina Neves Casarotti

sabrinacasarotti@yahoo.com.br

Ana Lúcia Barretto Penna

analucia@ibilce.unesp.br

1 Departamento de Engenharia e Tecnologia de Alimentos, Instituto de Biociências, Letras e Ciências Exatas, Universidade Estadual Paulista (UNESP), R. Cristovão Colombo, 2265, 15054-000 São José do Rio Preto, São Paulo, Brazil

2 Departamento de Alimentos e Nutrição, Faculdade de Nutrição, Universidade Federal de Mato Grosso (UFMT), 78060-900 Cuiabá, MT, Brazil

3 Instituto de Ciências Exatas e Naturais, Universidade Federal de Mato Grosso (UFMT), 78735-901 Rondonópolis, MT, Brazil

4 Departamento de Veterinária, Universidade Federal de Viçosa (UFV), 36570-000 Viçosa, MG, Brazil

5 Departamento de Biologia, Instituto de Biociências, Letras e Ciências Exatas, Universidade Estadual Paulista (UNESP), Rua Cristóvão Colombo, 2265, 15054-000 São José do Rio Preto, SP, Brazil presented resistance to several antibiotics, the resistance was limited to antibiotics to which the strains had intrinsic resistance. Furthermore, the strains presented a limited spread of genes encoding virulence factors and resistance to antibiotics, and none of the strains presented hemolytic or mucin degradation activity. The $L$. delbrueckii subsp. bulgaricus strains showed the lowest survival rate after exposure to simulated GI tract conditions, whereas all of the $L$. casei and L. fermentum strains showed good survivability. None of the tested lactobacilli strains presented bile salt hydrolase (BSH) activity, and only $L$. casei SJRP145 did not produce the $\beta$-galactosidase enzyme. The strains showed varied levels of adhesion to Caco- 2 cells. None of the cell-free supernatants inhibited the growth of pathogenic target microorganisms. Overall, L. fermentum SJRP30 and $L$. casei SJRP145 and SJRP146 were revealed to be safe and to possess similar or superior probiotic characteristics compared to the reference strain L. rhamnosus GG (ATCC 53103).

Keywords Lactic acid bacteria - Dairy $\cdot$ Safety $\cdot$ Antibiotic resistance $\cdot$ Beneficial properties $\cdot$ Gastrointestinal tract survival

\section{Introduction}

Lactobacillus spp. belong to the group of lactic acid bacteria (LAB) and have a long history of use in the production of dairy products due to their ability to convert lactose into lactic acid (Tulumoğlu et al. 2014). In addition to their use as technological agents in the food industry, some Lactobacillus species can confer health benefits to the host when they are administered adequately as probiotics. Probiotics are currently defined "as live microorganisms that, when administered in adequate amounts, confer health benefit on the host" (Hill et al. 2014). Although probiotics have been extensively 
studied and commercialized, and are the subject of national and international regulations, there is no agreement concerning the amount of probiotic bacteria necessary to produce their beneficial effects. Generally, probiotic food products must contain $10^{6} \mathrm{CFU} / \mathrm{mL}$ or CFU/g (Shah 2000). Nevertheless, some authors state that beneficial effects can be achieved even when bacteria lose their viability (Adams 2010).

Some of the health effects attributed to probiotic consumption include the regulation of gastrointestinal (GI) functions, relief of lactose intolerance, prevention of different types of diarrhea besides urogenital infections, reduction in cholesterol levels, reduction in atopic and food allergies, and modulation of the immune system. Furthermore, in vitro studies have shown that probiotic bacteria reduce the number of pathogens and their metabolic activities in the human intestine and compete with these microorganisms for attachment sites to intestinal epithelial cells and nutrients (Guarner and Malagelada 2003; Mishra et al. 2015).

Although a large number of probiotic strains are available for commercial use worldwide, the isolation and characterization of new strains from different species is desirable; thus, many studies in this field have been published in recent years (Jeronymo-Ceneviva et al. 2014; Peres et al. 2014; de Paula et al. 2015; Oh and Jung 2015). Probiotics targeted for human consumption are usually isolated from humans or animals because strains from these origins can better adapt to the conditions encountered in the human/animal GI tract, which enables more successful gut colonization (Argyri et al. 2013). However, certain food-associated Lactobacillus strains have probiotic characteristics even though they do not belong to the gut microbiota (Solieri et al. 2014; Tulumoğlu et al. 2014).

According to the FAO/WHO (2002), a bacterial strain should fulfill a number of requirements to be considered probiotic; these requirements must be verified by in vitro and in vivo tests. In vitro tests are useful for the selection of strains that have greater probiotic potential; these tests increase knowledge regarding the strain as well as the mechanisms underlying the beneficial effects. Although LAB, particularly Lactobacillus, are generally recognized as safe (GRAS), additional tests should be performed to check the safety of these strains because some cases recently associated systemic infection with the consumption of probiotics (Liong 2008; Sharma and Devi 2014). Thus, evaluating their safety, assessing their resistance to antibiotics, investigating the presence of virulence genes, and determining hemolytic activity are important (Jeronymo-Ceneviva et al. 2014; Vijayakumar et al. 2015).

Given these points, the aim of this study was to characterize the safety features and probiotic potential attributes of autochthonous Lactobacillus spp. isolated from water buffalo mozzarella cheese using in vitro tests. Candidates that met the established criteria may be used in the production of fermented products to promote their probiotic characteristics.

\section{Materials and methods}

\section{Bacterial strains}

Ten Lactobacillus strains previously isolated and identified through 16S rRNA gene sequencing by our group (Silva et al. 2015; Silva 2015) as Lactobacillus fermentum (SJRP30), Lactobacillus casei (SJRP37, SJRP66, SJRP141, SJRP145, SJRP146, and SJRP169), and Lactobacillus delbrueckii subsp. bulgaricus (SJRP50, SJRP76 and SJRP149) were screened for their safety and probiotic potential. Lactobacillus rhamnosus GG (ATCC 53103) was used as a probiotic reference strain. The strains were maintained at $-80{ }^{\circ} \mathrm{C}$ in MRS broth (Difco, Becton Dickinson, Sparks, MD) supplemented with $25 \%(\mathrm{v} / \mathrm{v})$ glycerol (Vetec, Duque de Caxias, RJ, Brazil). Each culture was sub-cultured at least twice in MRS broth before use in the assays.

\section{Assessment of safety characteristics}

\section{Hemolytic activity}

Fresh lactobacilli broth cultures (8.0-9.0 $\log \mathrm{CFU} / \mathrm{mL})$ were streaked in triplicate on Columbia agar plates containing 5\% (w/v) sheep blood (NewProv, Pinhais, PR, Brazil). After $48 \mathrm{~h}$ of incubation at $37^{\circ} \mathrm{C}$, the plates were examined for hemolytic reactions. The Lactobacillus rhamnosus GG (ATCC 53103) and Staphylococcus aureus ATCC 6538 strains were used as the negative and positive controls, respectively (Pieniz et al. 2014). The assay was repeated on three independent occasions in triplicate.

\section{Mucin degradation}

Mucin degradation was determined according to Zhou et al. (2001). Salmonella enterica subsp. enterica serovar Typhimurium ATCC 14028 and Lactobacillus rhamnosus GG (ATCC 53103) were used as the positive and negative controls, respectively. The assay was repeated on three independent occasions in triplicate.

Presence of genes encoding virulence factors, antibiotic resistance and biogenic amines

The Lactobacillus strains were tested for the presence of virulence, antibiotic resistance and amino acid decarboxylase genes (Table 1). DNA was extracted using the QIAgen DNeasy Blood \& Tissue Kit (Qiagen, Hilden, Germany), followed by DNA concentration estimation using the NanoDrop2000 spectrophotometer (Thermo Scientific, Waltham, MA). PCRs were performed according to the references listed in Table 1, and the amplified products were separated by electrophoresis in 0.8 to $2.0 \%(\mathrm{w} / \mathrm{v})$ agarose gels in 


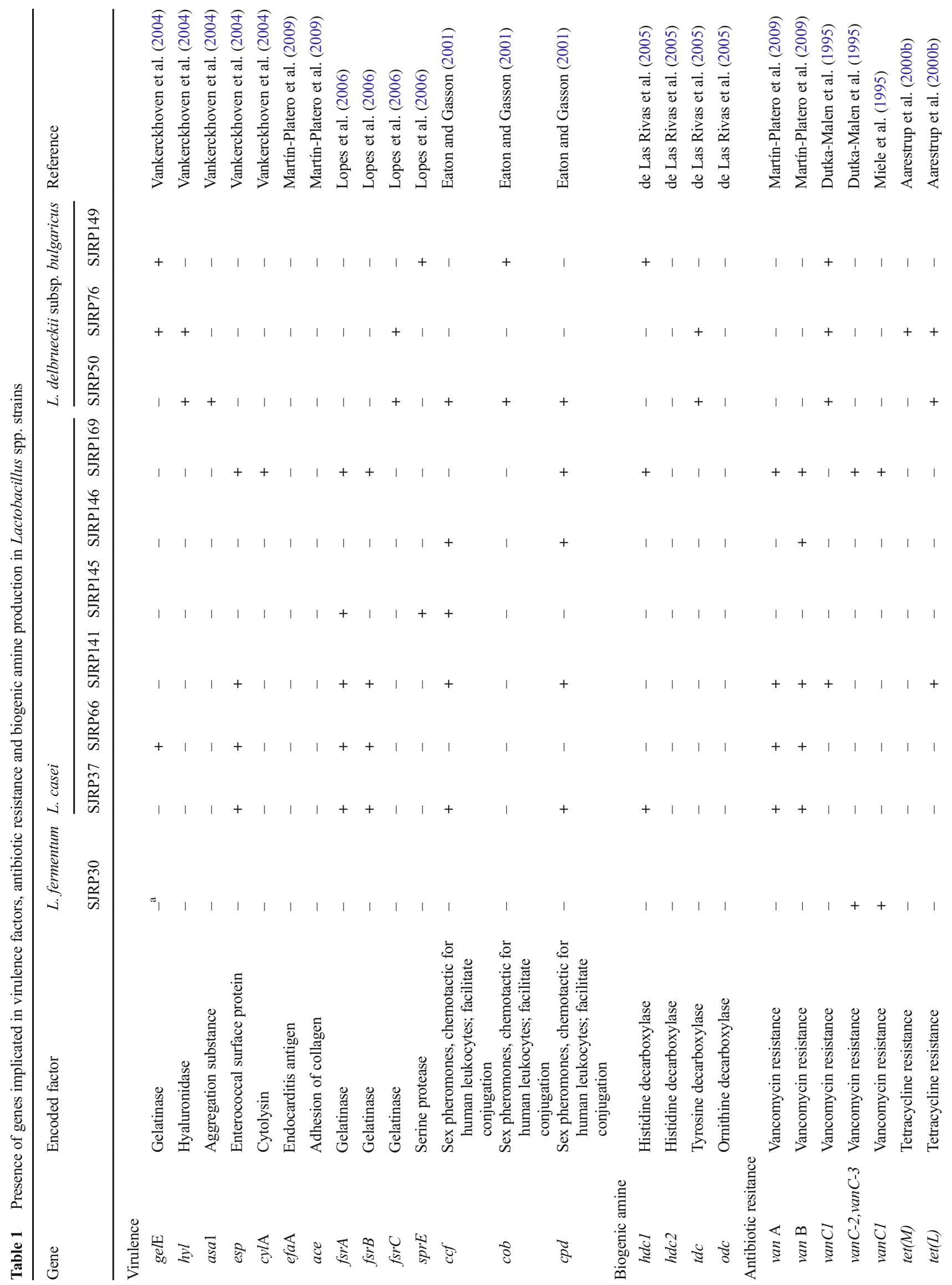




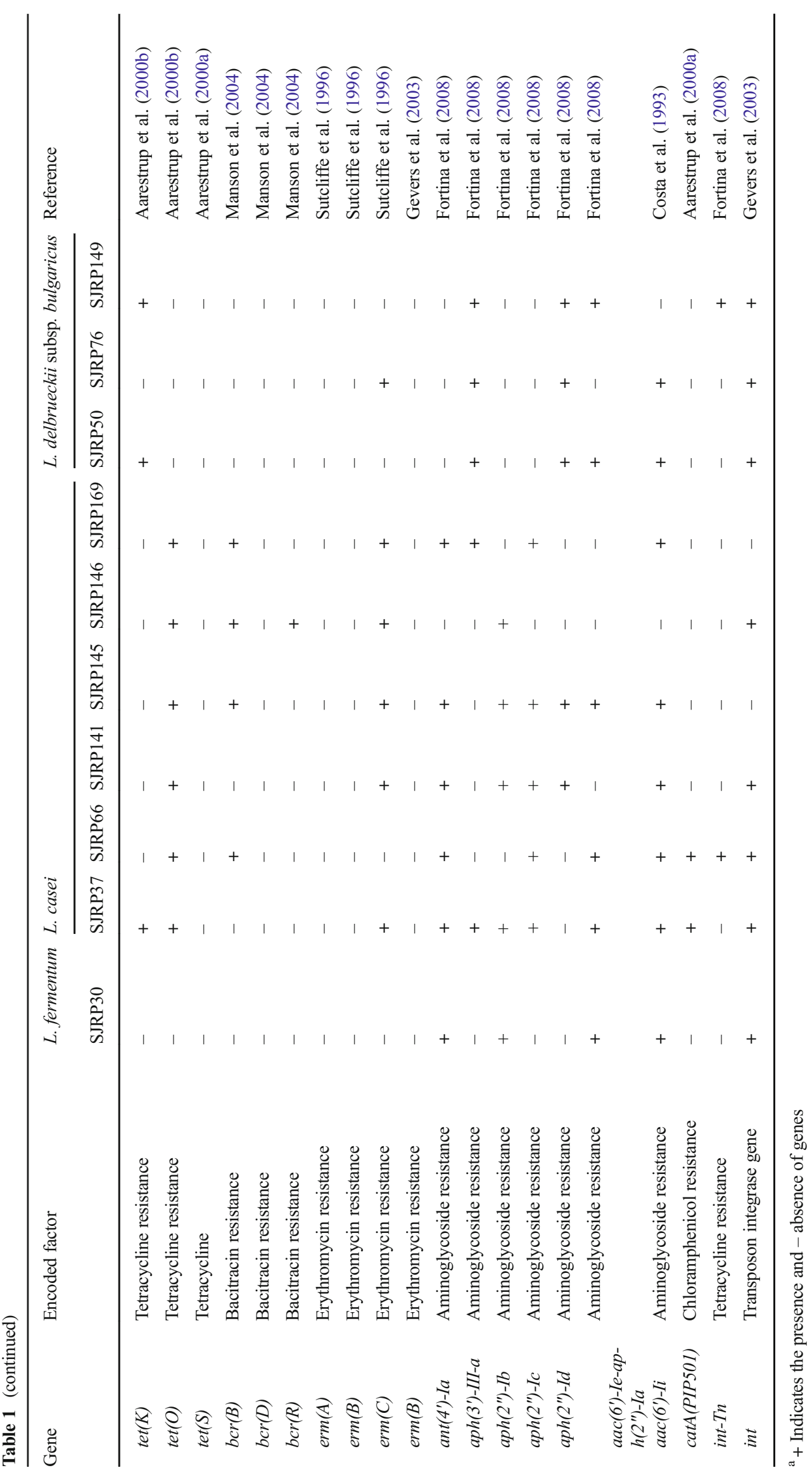


$0.5 \times$ TAE buffer. The gels were stained in $0.5 \times$ TAE buffer containing $0.5 \mu \mathrm{g} / \mathrm{mL}$ of ethidium bromide (Sigma-Aldrich, St. Louis, MO).

\section{Antibiotic susceptibility}

The disc diffusion assay was applied to determine the antibiotic susceptibility of the strains. Diluted culture $(100 \mu \mathrm{L} ; 6.0$ $\log \mathrm{CFU} / \mathrm{mL}$ ) was spread onto MRS agar media (Difco), and antibiotic discs (Oxoid, Basingstoke, UK) containing (per disc) ampicillin $(10 \mu \mathrm{g})$, vancomycin $(30 \mu \mathrm{g})$, gentamicin $(10 \mu \mathrm{g})$, kanamycin $(30 \mu \mathrm{g})$, streptomycin $(300 \mu \mathrm{g})$, tetracycline $(30 \mu \mathrm{g})$, chloramphenicol $(30 \mu \mathrm{g})$, erythromycin $(15 \mu \mathrm{g})$, and clindamycin $(2 \mu \mathrm{g})$ were placed manually on the surface of the inoculated plates using sterile forceps. These antibiotics were chosen according to the list proposed by the European Food Safety Authority (EFSA 2012). The plates were incubated at $37{ }^{\circ} \mathrm{C}$ under anaerobic conditions, and the diameters of the inhibition zones were evaluated $24 \mathrm{~h}$ after incubation. The susceptibility of the isolates was scored as resistant, moderately susceptible, or susceptible according to the cut-off values proposed by Charteris et al. (1998). The assay was repeated on three independent occasions in triplicate.

\section{Assessment of probiotic potential characteristics}

\section{Tolerance to simulated GI tract conditions}

The tolerance to simulated GI tract conditions test was performed by successively exposing the strains to gastric and enteric simulated juices as described by Botta et al. (2014). The lactobacilli strains were grown for $18 \mathrm{~h}$ at $37{ }^{\circ} \mathrm{C}$ in MRS broth, and $1 \mathrm{~mL}$ of each culture $(8.0-9.0 \mathrm{CFU} / \mathrm{mL})$ was distributed into four sterile flasks (two for the gastric phase and two for the enteric phase). The solutions simulating the gastric and enteric juices were prepared according to the method of Bautista-Gallego et al. (2013). The $\mathrm{pH}$ values used in the gastric and enteric phases were 2.5 and 8.0, respectively. All enzyme solutions were prepared and filter-sterilized using a $0.22-\mu \mathrm{m}$ membrane filter (Merck Millipore, Cork, Ireland) on the day of analysis.

The cells were counted at the beginning $\left(\mathrm{T}_{0}\right)$ and the end of the gastric phase $\left(T_{120}\right)$ and after the enteric phase $\left(T_{360}\right)$. The cell count was performed by serial dilution and plating in MRS agar (Difco). The plates were incubated at $37{ }^{\circ} \mathrm{C}$ for $48 \mathrm{~h}$ under anaerobic conditions (Anaerobac, Probac, São Paulo, Brazil). The commercial probiotic L. rhamnosus GG (ATCC 53103) was used as a reference strain. The assay was repeated on three independent occasions in duplicate.

\section{Bile salt hydrolase activity}

Fresh bacterial cultures of the studied lactobacilli (8.0-9.0 log $\mathrm{CFU} / \mathrm{mL}$ ) were screened for bile salt hydrolase (BSH) activity as previously described by de Paula et al. (2014) using MRS plates supplemented with taurodeoxycholic acid sodium salt (TDCA) or taurocholic acid sodium salt hydrate (TC); MRS plates without TDCA and TC were used as negative controls, whereas L. mesenteroides SJRP 55 was used as a positive control. The plates were incubated anaerobically at $37^{\circ} \mathrm{C}$ for $48 \mathrm{~h}$. The presence of precipitated bile acid around the spots was considered a positive result (Rodríguez et al. 2012). The assay was repeated on three independent occasions in triplicate.

\section{Adhesion to Caco-2 cells}

The Caco-2 cell line BCRJ 0059 (Rio de Janeiro Cell Bank, Rio de Janeiro, Brazil) was cultured (passages 29-31) in Dulbecco's modified Eagle's minimum (DMEM, SigmaAldrich) supplemented with $10 \%$ heat-inactivated fetal bovine serum (Cultilab, Campinas, Brazil), a mixture of penicillin $(100 \mathrm{UI} / \mathrm{mL})$ and streptomycin $(100 \mu \mathrm{g} / \mathrm{mL})$ (SigmaAldrich), and $1 \%$ non-essential amino acid solution (SigmaAldrich) at $37^{\circ} \mathrm{C}$ in a $5 \% \mathrm{CO}_{2}$ atmosphere.

The adhesion assay was performed as described by Argyri et al. (2013). All bacterial cultures were grown for $18 \mathrm{~h}$ in MRS at $37^{\circ} \mathrm{C}$ before the assays, harvested by centrifugation $\left(7000 \mathrm{~g}, 7 \mathrm{~min}, 5^{\circ} \mathrm{C}\right)$, washed twice with phosphate-buffered saline (PBS) and re-suspended in DMEM without any serum or antibiotics. The commercial probiotic L. rhamnosus GG (ATCC 53103) was used as a reference strain. Subsequently, $1 \mathrm{~mL}$ containing approximately 8.0-9.0 log CFU bacterial cells was added to each well, and each strain was evaluated for adherence in duplicate wells in each experiment. After incubation for $2 \mathrm{~h}$ at $37^{\circ} \mathrm{C}$, the cells were washed three times with sterile PBS to remove non-adherent bacteria, and then detached from each well by the addition of $1 \mathrm{~mL}$ Triton X-100 $(0.5 \% \mathrm{v} / \mathrm{v})$ (Sigma-Aldrich). Following incubation for $5 \mathrm{~min}$ at $37^{\circ} \mathrm{C}$, the cell lysates were serially diluted and plated on MRS agar. Bacterial adhesion (\%) was calculated by the ratio of adhered bacteria to the total number of added bacteria. The experiment was performed on three independent occasions.

Presence of genes encoding adhesion, aggregation and colonization factors

The investigated Lactobacillus strains were tested for the presence of adhesion, aggregation and colonization genes (Table 2) as described in the section "Presence of genes encoding virulence factors, antibiotic resistance and biogenic amines". 


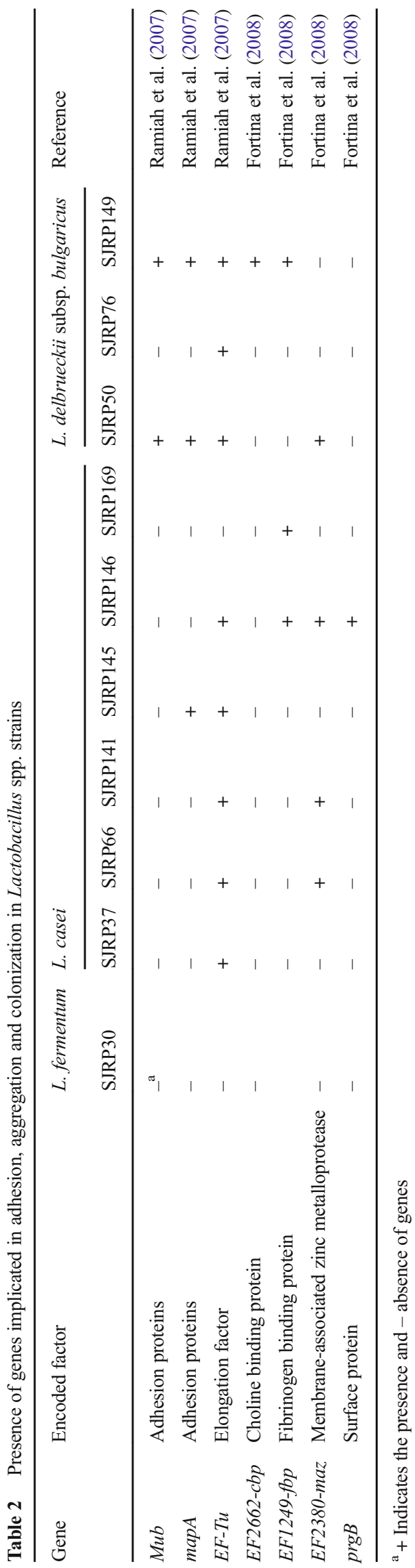

Antimicrobial activity

All lactobacilli strains were tested for antimicrobial activity against Escherichia coli ATCC 25922, E. coli ATCC 8739, Listeria innocua ATCC 33090, Listeria monocytogenes ATCC 15313, Klebsiella pneumoniae subsp. pneumoniae ATCC 10031, Staphylococcus aureus subsp. aureus ATCC 25923, Salmonella enterica subsp. enterica serovar Typhimurium ATCC 14028 and Shigella sonnei ATCC 25931 according to the method described by de Paula et al. (2014). The antibiotic ciprofloxacin $(5 \mu \mathrm{g})$ was used as a positive control, whereas MRS broth adjusted to $\mathrm{pH} 6.5$ and filtered was used as a negative control. The assay was repeated on three independent occasions in triplicate.

\section{$\beta$-Galactosidase activity}

The $\beta$-galactosidase activity of the Lactobacillus spp. strains was assessed by employing sterile filter paper discs impregnated with $o$-nitrophenyl- $\beta$-D-galactopyranose (ONPG Discs, Fluka, Buchs, Switzerland) according to the manufacturer's instructions. The test was performed in three independent experiments in duplicate. $S$. enterica subsp. enterica serovar Typhimurium ATCC 14028 and E. coli ATCC 25922 were used as the negative and positive controls, respectively.

\section{Statistical analysis}

The statistical analysis was performed using the Statistica 7.0 software (StatSoft, Inc., 2004, Tulsa, OK). One-way ANOVA followed by Tukey's test was applied to detect significant differences $(P \leq 0.05)$ in the data regarding tolerance to simulated GI tract conditions and in vitro adhesion to Caco- 2 cells.

\section{Results}

\section{Hemolytic activity}

None of the examined strains revealed $\beta$-hemolytic (i.e., red blood cell lysis) activity when grown in Columbia sheep blood agar. Most of the strains (L. fermentum SJRP30 and L. casei strains SJRP37, SJRP66, SJRP145, SJRP146, and SJRP169) were $\gamma$-hemolytic (i.e., no hemolysis), whereas four strains showed partial hemolysis (L. delbrueckii subsp. bulgaricus SJRP50, SJRP76, and SJRP149 and L. casei SJRP141). Staphylococcus aureus ATCC 6538 (positive control) showed hemolytic activity.

\section{Mucin degradation}

Neither the Lactobacillus spp. nor the reference strain (negative control) showed mucinolytic activity in either type of 
tested medium (with or without glucose). Conversely, S. enterica subsp. enterica serovar Typhimurium ATCC 14028 (positive control) was able to degrade mucin in vitro in a medium in which mucin was the only energy source.

\section{Presence of genes encoding virulence factors, antibiotic resistance and biogenic amines}

None of the tested isolates presented a positive result for the efa $A, a c e, h d c 2, \operatorname{odc}, \operatorname{tet}(S), \operatorname{erm}(A)$, and $\operatorname{erm}(B)$ genes, which were related to endocarditis antigen, collagen adhesion, tyrosine decarboxylase, ornithine decarboxylase, tetracycline resistance and erythromycin resistance, respectively (Table 1). L. casei SJRP169 had the highest frequency of genes encoding virulence factors, antibiotic resistance and biogenic amines (42.55\%). Conversely, the L. fermentum SJRP30 strain showed the lowest frequency $(14.89 \%)$ of positive results.

\section{Antibiotic susceptibility}

All of the strains were sensitive to ampicillin, tetracycline, chloramphenicol, erythromycin, and clindamycin, which are frequently used to treat bacterial infections (Table 3). All of the L. delbrueckii subsp. bulgaricus strains were sensitive to vancomycin and gentamicin, whereas the other strains were resistant. Most strains were susceptible to streptomycin, with the exception of $L$. fermentum SJRP30, which was classified as moderately susceptible. All of the tested strains were classified as resistant to kanamycin.

\section{Tolerance to simulated GI tract conditions}

There was a significant decrease $(P \leq 0.05)$ in the populations of all strains evaluated after consecutive exposure to the gastric and small intestine conditions (Fig. 1). The L. delbrueckii subsp. bulgaricus strains showed the lowest population at the end of the in vitro assay, with a cell count reduction of $3.38 \log \mathrm{CFU} / \mathrm{mL}$ on average. In contrast, L. casei and L. fermentum showed good viability during the simulated GI digestion, with reductions of $0.85-2.48$ $\log$ units (Fig. 1). Two groups of tolerance were outlined after exposure to simulated gastric juice at $\mathrm{pH} 2.5 ; \mathrm{L}$. casei SJRP37, SJRP66, SJRP141, SJRP145, SJRP146 and SJRP169, L. delbrueckii subsp. bulgaricus SJRP76 and L. rhamnosus GG maintained the same populations, whereas L. fermentum SJRP30 and L. delbrueckii subsp. bulgaricus SJRP50 and SJRP149 showed a significant $(P \leq 0.05)$ reduction in their populations. Tolerance to the enteric condition was variable among the strains. The L. fermentum SJRP30 and L. casei SJRP146 strains suffered a reduction of less than $1 \log$ unit after exposure to simulated enteric juice. The other L. casei strains and L. delbrueckii subsp. bulgaricus SJRP50 suffered a reduction between 1 and $2 \log$ units, whereas $L$. delbrueckii subsp. bulgaricus SJRP76 and SJRP149 revealed a reduction of 3.07 and $3.59 \log \mathrm{CFU} / \mathrm{mL}$, respectively.

\section{BSH activity}

All $L$. casei and $L$. fermentum strains were able to grow in MRS agar plates containing $0.5 \%(\mathrm{w} / \mathrm{v})$ TDCA sodium salts, whereas the growth of L. delbrueckii subsp.

Table 3 Antibiotic susceptibility ${ }^{\text {a }}$ of Lactobacillus spp. strains. AMP Ampicillin, VA vancomycin, $C N$ gentamicin, $K$ kanamycin, $S$ streptomycin, $T E$ tetracycline, $C$ chloramphenicol, $E$ erythromycin, $D A$ clindamycin

\begin{tabular}{|c|c|c|c|c|c|c|c|c|c|c|}
\hline Species & Strains & $\begin{array}{l}\text { AMP } \\
(10 \mu \mathrm{g})\end{array}$ & $\begin{array}{l}\text { VA } \\
(30 \mu g)\end{array}$ & $\begin{array}{l}\mathrm{CN} \\
(10 \mu \mathrm{g})\end{array}$ & $\begin{array}{l}\mathrm{K} \\
(30 \mu \mathrm{g})\end{array}$ & $\begin{array}{l}\text { S } \\
(300 \mu g)\end{array}$ & $\begin{array}{l}\mathrm{TE} \\
(30 \mu \mathrm{g})\end{array}$ & $\begin{array}{l}\mathrm{C} \\
(30 \mu \mathrm{g})\end{array}$ & $\begin{array}{l}\mathrm{E} \\
(15 \mu \mathrm{g})\end{array}$ & $\begin{array}{l}\text { DA } \\
(2 \mu \mathrm{g})\end{array}$ \\
\hline L. fermentum & SJRP30 & $29 \mathrm{~S}$ & $0 \mathrm{R}$ & $9 \mathrm{R}$ & $0 \mathrm{R}$ & $14 \mathrm{MS}$ & $26 \mathrm{~S}$ & $27 \mathrm{~S}$ & $27 \mathrm{~S}$ & $27 \mathrm{~S}$ \\
\hline \multirow[t]{6}{*}{ L. casei } & SJRP37 & $29 \mathrm{~S}$ & $0 \mathrm{R}$ & $9 \mathrm{R}$ & $0 \mathrm{R}$ & $19 \mathrm{~S}$ & $30 \mathrm{~S}$ & $29 \mathrm{~S}$ & $30 \mathrm{~S}$ & $27 \mathrm{~S}$ \\
\hline & SJRP66 & $32 \mathrm{~S}$ & $0 \mathrm{R}$ & $13 \mathrm{~S}$ & $0 \mathrm{R}$ & $23 \mathrm{~S}$ & $35 \mathrm{~S}$ & $31 \mathrm{~S}$ & $37 \mathrm{~S}$ & $34 \mathrm{~S}$ \\
\hline & SJRP141 & $33 \mathrm{~S}$ & $0 \mathrm{R}$ & $12 \mathrm{R}$ & $0 \mathrm{R}$ & $26 \mathrm{~S}$ & $36 \mathrm{~S}$ & $29 \mathrm{~S}$ & $37 \mathrm{~S}$ & $33 \mathrm{~S}$ \\
\hline & SJRP145 & $28 \mathrm{~S}$ & $0 \mathrm{R}$ & $10 \mathrm{R}$ & $0 \mathrm{R}$ & $20 \mathrm{~S}$ & $31 \mathrm{~S}$ & $27 \mathrm{~S}$ & $31 \mathrm{~S}$ & $27 \mathrm{~S}$ \\
\hline & SJRP146 & $33 \mathrm{~S}$ & $0 \mathrm{R}$ & $13 \mathrm{~S}$ & $0 \mathrm{R}$ & $22 \mathrm{~S}$ & $38 \mathrm{~S}$ & $32 \mathrm{~S}$ & $37 \mathrm{~S}$ & $32 \mathrm{~S}$ \\
\hline & SJRP169 & $35 \mathrm{~S}$ & $0 \mathrm{R}$ & $14 \mathrm{~S}$ & $0 \mathrm{R}$ & $25 \mathrm{~S}$ & $36 \mathrm{~S}$ & $34 \mathrm{~S}$ & $36 \mathrm{~S}$ & $33 \mathrm{~S}$ \\
\hline \multirow{3}{*}{$\begin{array}{l}\text { L. delbrueckii subsp. } \\
\text { bulgaricus }\end{array}$} & SJRP50 & $28 \mathrm{~S}$ & $21 \mathrm{~S}$ & $10 \mathrm{R}$ & $11 \mathrm{R}$ & $24 \mathrm{~S}$ & $31 \mathrm{~S}$ & $29 \mathrm{~S}$ & $32 \mathrm{~S}$ & $30 \mathrm{~S}$ \\
\hline & SJRP76 & $27 \mathrm{~S}$ & $21 \mathrm{~S}$ & $10 \mathrm{R}$ & $7 \mathrm{R}$ & $23 \mathrm{~S}$ & $31 \mathrm{~S}$ & $30 \mathrm{~S}$ & $32 \mathrm{~S}$ & $29 \mathrm{~S}$ \\
\hline & SJRP149 & $38 \mathrm{~S}$ & $23 \mathrm{~S}$ & $10 \mathrm{R}$ & $0 \mathrm{R}$ & $25 \mathrm{~S}$ & $31 \mathrm{~S}$ & $30 \mathrm{~S}$ & $33 \mathrm{~S}$ & $31 \mathrm{~S}$ \\
\hline L. rhamnosus GG & $\begin{array}{l}\text { ATCC } \\
53103\end{array}$ & $30 \mathrm{~S}$ & $0 \mathrm{R}$ & $10 \mathrm{R}$ & $0 \mathrm{R}$ & $22 \mathrm{~S}$ & $33 \mathrm{~S}$ & $31 \mathrm{~S}$ & $32 \mathrm{~S}$ & $28 \mathrm{~S}$ \\
\hline
\end{tabular}

\footnotetext{
${ }^{a}$ Inhibition zones were measured in millimeters, and the susceptibility of the isolates was scored as resistant (R), moderately susceptible (MS) and susceptible (S) according to the cut-off values proposed by Charteris et al. (1998)
} 


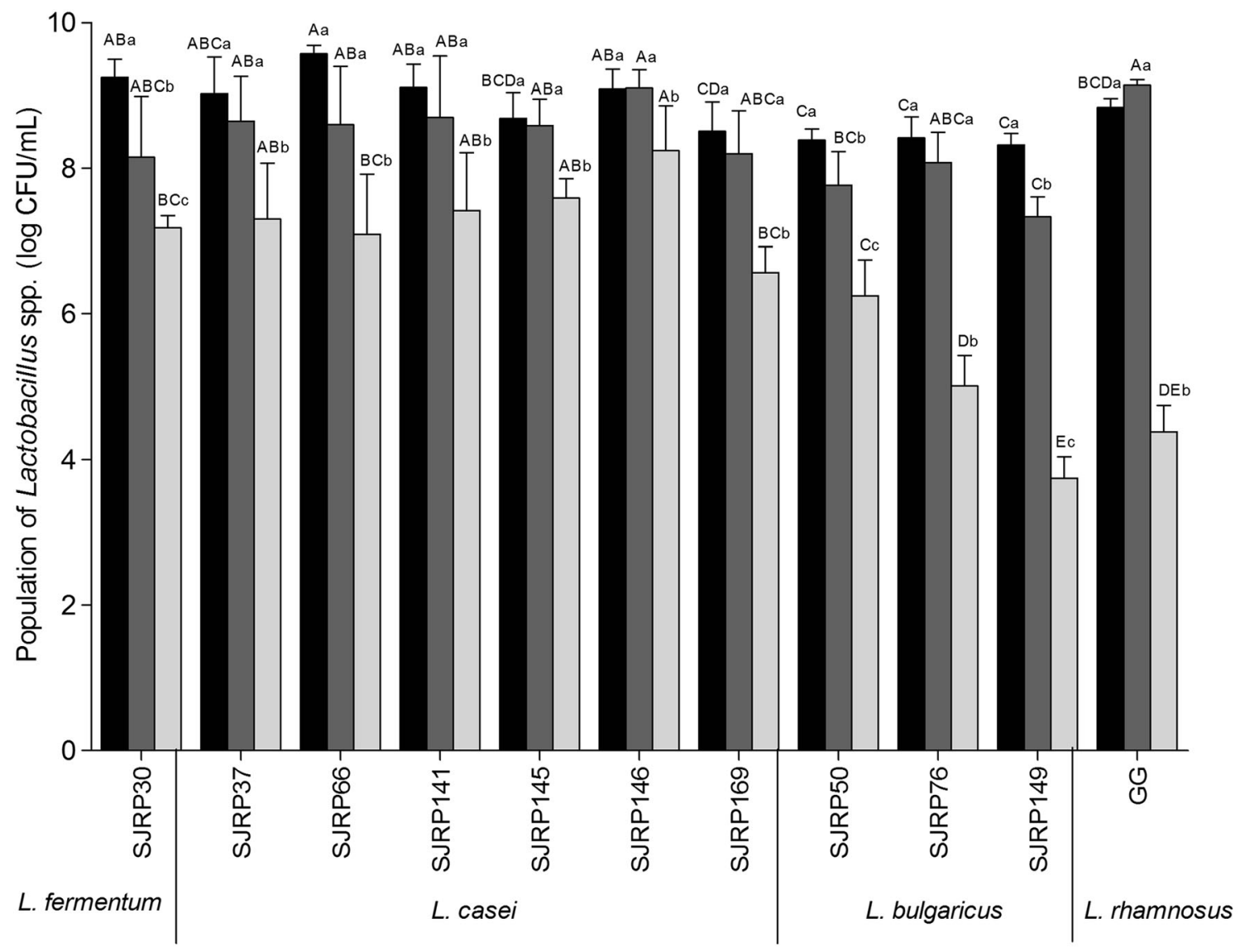

Fig. 1 Survival of Lactobacillus spp. strains before ( $\square$ ) and during exposure to in vitro simulated gastric conditions for $120 \mathrm{~min}(\square$, $\mathrm{pH} 2.5)$ and enteric conditions for $360 \mathrm{~min}(\square, \mathrm{pH}$ 8). Different capital letters denote significant differences $(P \leq 0.05)$ among strains

bulgaricus was completely inhibited. Conversely, all strains grew in MRS agar plates with $0.5 \%(w / v)$ TC. Nevertheless, none of the tested lactobacilli strains showed BSH activity.

\section{Adhesion to Caco-2 cells}

All of the tested strains could adhere to Caco-2 cells, but they did so to different degrees. The adhesion rates ranged from $2.59 \%$ to $18.58 \%$. L. fermentum SJRP30, L. casei strains SJRP37, SJRP145, and SJRP146 and L. delbrueckii subsp. bulgaricus SJRP76 showed similar adherence to the reference strain after $2 \mathrm{~h}$ of incubation $(P \leq 0.05)$. L. casei SJRP141 was the most adhesive strain and presented adherent bacteria counts higher than the positive control L. rhamnosus GG. L. casei SJRP66 and L. delbrueckii subsp. bulgaricus SJRP149 had the lowest adhesion capacities. The results indicate that adhesion properties are strain-specific because the strains do not show similar adhesion values even though they are from the same species or genus (Fig. 2). during the same sampling period of the in vitro assay. Different lower case letters denote significant differences $(P \leq 0.05)$ among sampling periods for the same strain in the in vitro assay. The results are expressed as the mean \pm SD. $n=3$

\section{Presence of genes encoding adhesion, aggregation and colonization factors}

L. delbrueckii subsp. bulgaricus SJRP149 showed positive results for all tested genes encoding adhesion, aggregation and colonization factors with the exception of the $\operatorname{prg} B$ gene. In contrast, strain $L$. fermentum SJRP30 did not harbor any of these genes. The other studied strains possessed at least one of the genes (Table 2).

\section{Antimicrobial activity}

The growth of pathogenic target microorganisms was not inhibited by any of the cell-free supernatants (CFS) (adjusted to $\mathrm{pH}$ 6.5) obtained from the tested LAB strains (data not shown).

\section{$\beta$-galactosidase activity}

Strains L. casei SJRP146 and L. delbrueckii subsp. bulgaricus SJRP50 and SJRP76 displayed an intense yellow color in their 


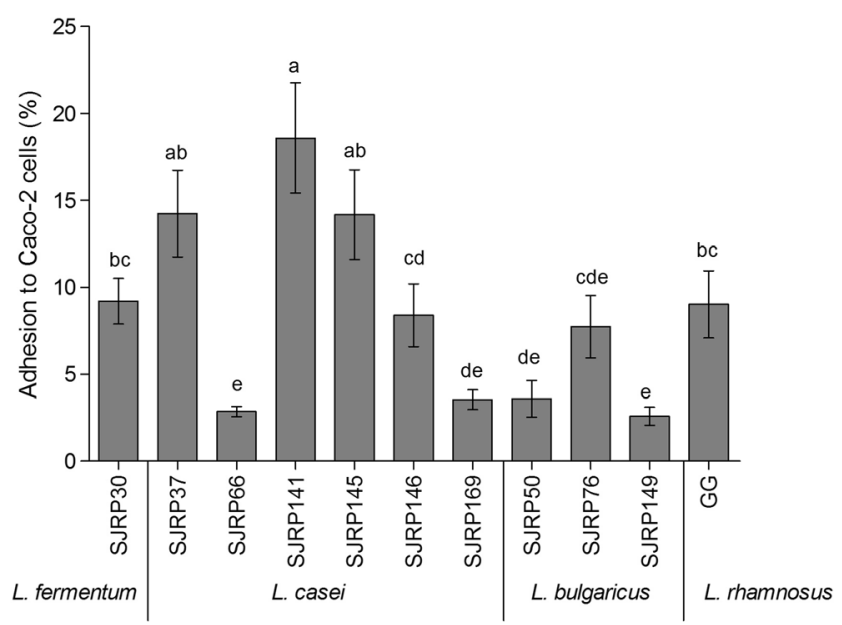

Fig. 2 Adhesion capacity of Lactobacillus spp. strains to Caco-2 cells. The adhesion capacity is calculated using the ratio of the number of bacterial cells that remained attached to the total number of bacterial cells added initially to each well. Different lower case letters denote significant differences $(P \leq 0.05)$ among the adhesion capacities of the strains. The results are expressed as the mean \pm SD. $n=3$

tests. The other strains, except for L. casei SJRP145, also showed positive results; however, these strains produced a less intense yellow color. The reference strain L. rhamnosus GG and $L$. casei SJRP145 did not present $\beta$-galactosidase activity.

\section{Discussion}

In this study, we performed an in vitro analysis to determine the safety and probiotic potential characteristics of ten Lactobacillus strains. The assays were chosen based on international guidelines for evaluation of probiotic potential (FAO/ WHO 2002). Although a large number of studies has been published in this field in the past, the identification of new strains with probiotic potential is always desirable, mainly because each strain shows different methods of action and several benefits to health. Nevertheless, before being used as a probiotic, the safety of the strains needs to be assessed to ensure that they will not represent a risk to consumer health. Recently, some cases relating infections to probiotic consumption have been reported (Kochan et al. 2011; Zbinden et al. 2015). Therefore, determining whether a strain is safe is of great concern among researchers.

A lack of hemolytic activity is considered a safety requirement when selecting a probiotic strain (FAO/WHO 2002) because such bacteria are not virulent, and the lack of hemolysin ensures that opportunistic virulence will not appear among strains (Peres et al. 2014). Previous reports also revealed that different LAB species did not show hemolysis (Argyri et al. 2013; Bautista-Gallego et al. 2013; Ryu and Chang 2013; Ilavenil et al. 2015). The production of enzymes capable of degrading mucin was proposed as a determinant factor of virulence for some enteropathogens. Therefore, this property is not considered a desirable feature for probiotic strains because it contributes to changes in the intestinal mucosal barrier in addition to favoring mucosal invasion by pathogens and other toxic agents (Monteagudo-Mera et al. 2012; Peres et al. 2014). Our results suggest that the evaluated probiotic candidates may not be able to invade the intestinal mucosa. These findings were in agreement with previous studies that investigated mucin degradation by several LAB species (Fernández et al. 2005; Abe et al. 2010; Rodríguez et al. 2012).

The main concern regarding probiotic safety is the resistance to antibiotics because these strains may transfer antibiotic resistance genes to pathogenic bacteria in the intestinal habitat, which can represent a serious risk for the treatment of infected patients. Antibiotic resistance is considered a negative characteristic for probiotics (Lee et al. 2014). The strains were found to be resistant to vancomycin, gentamicin, streptomycin, and kanamycin; however, this resistance pattern is considered an intrinsic feature of LAB because it is chromosomally encoded and, thus, the corresponding genes will not be transferred to pathogens (Tulini et al. 2013; Botta et al. 2014; Sharma et al. 2015). Taking these reports into consideration, the resistance to vancomycin, kanamycin, streptomycin, and gentamicin found in the strains and in the reference strain L. rhamnosus GG can be considered acceptable.

During the course of testing the strains for the presence of virulence genes, at least one of the genes responsible for gelatinase production ( $g e l E, f_{s} r A, f_{s} r B$ and $f_{s} r C$ ) was detected in all strains except L. fermentum SJPR30. The gelE gene is responsible for the production of gelatinase, which is an enzyme that hydrolyzes gelatin and collagen. Moreover, gelE expression is thought to be regulated in a cell densitydependent manner by the products of $f_{s r} A, f_{s r} B$ and $f_{s r} C$. However, the presence of gelE does not seem to be sufficient for gelatinase activity, and a complete $f_{s r}$ operon may be mandatory for gelE expression (Lopes et al. 2006). In our study, none of the strains contained the complete $f_{s r}$ operon.

Only L. casei SJRP169 presented the cylA gene; however, four isolates (L. casei SJRP141 and L. delbrueckii subsp. bulgaricus SJRP50, SJRP76 and SJRP149) showed partial hemolysis in the phenotypic test, whereas SJRP169 did not. Other lytic genes most likely cause this hemolytic reaction in the phenotypic tests when the $c y l A$ gene is not expressed (Perin et al. 2014). Four L. casei strains contained the esp gene, which may be a result of horizontal transference by the Enterococcus genus. Conversely, the adhesion properties conferred by the esp gene can be a significant characteristic for potential probiotic bacteria (de Paula et al. 2014). Sex pheromone genes ( $c c f, c o b$ and $c p d$ ) were present in some of the evaluated strains. These genes are also considered virulence factors because they might induce an inflammatory response. Moreover, these genes have shown 
in vitro chemotactic activity for human and rat polymorphonuclear leukocytes, and elicited superoxide production and the secretion of lysosomal enzymes (Eaton and Gasson 2001).

Genes encoding antibiotic resistance were also tested. The antibiotic resistance genes vanA and vanB were frequently present among the tested strains. Almost all of the L. casei strains showed positive results for both genes, except $L$. casei SJRP145 and L. casei SJRP146 in which the vanA gene was absent. The vanC genes were harbored by L. fermentum SJRP30, L. casei SJRP141 and SJRP169 and all of the L. delbrueckii subsp. bulgaricus strains. The vanA phenotype is characterized by a higher resistance level to vancomycin than the van $B$ phenotype and cross-resistance to teicoplanin. The gene cluster for both $v a n A$ and $v a n B$ resistance is usually located on a plasmid that is transferable, and thus represents a major concern for safety due to the spread of antibiotic resistance via horizontal gene transfer (Klein et al. 2000; Perin et al. 2014). Conversely, vanC is located in the bacterial chromosome (Martín-Platero et al. 2009). Therefore, despite the observation of resistance during the disc diffusion test, the resistance towards vancomycin in L. fermentum SJRP30 and L. casei SJRP145 recorded in our study was considered intrinsic, chromosomally encoded, and not inducible or transferable (Tynkkynen et al. 1998). The lack of genes encoding vancomycin resistance has been reported (Casado Muñoz et al. 2014). However, other studies have demonstrated the presence of vanA and vanB genes in a variety of LAB (JeronymoCeneviva et al. 2014; Perin et al. 2014).

In this study, all strains contained at least one gene encoding aminoglycoside resistance, which could be associated with the intrinsic resistance towards this antibiotic class among Lactobacillus spp. The most common tetracycline resistance gene among Lactobacillus spp. strains was tet( $O)$, which was detected in all of the L. casei strains. However, tet $(S)$ was not recorded in any of the strains. Tetracycline resistance genes have been found in other Lactobacillus spp. strains isolated from fermented dry sausages, cheese and yogurt (Zonenschain et al. 2009; Zhou et al. 2012). The int gene was detected in eight strains, indicating that these strains might harbor the transposon responsible for tet gene dissemination. Although the int gene has not been found in Lactobacillus strains to date, it has been identified in Enterococcus and Lactococcus strains with food origins (Bulajić et al. 2015; Morandi et al. 2015; Jaimee and Halami 2016). Regarding erythromycin resistance, only the erm(C) gene was found among the Lactobacillus sp. strains. This gene was previously detected in a variety of Lactobacillus species (Kastner et al. 2006; Klare et al. 2007; Egervärn et al. 2009).

The $h d c l$ and $t d c$ genes, which are related to biogenic amine production, were present in five strains. The $h d c l$, $h d c 2, t d c$ and $o d c$ genes express enzymes that degrade histamine, tyramine and ornithine into biogenic amines, respectively. Low levels of biogenic amines in food are not considered a serious risk to the consumer; however, they can be toxic when present in high concentrations $(50-100 \mathrm{mg}$ ) (Jeronymo-Ceneviva et al. 2014). The presence of these genes has been reported for other LAB (Coton et al. 2010; Jeronymo-Ceneviva et al. 2014).

Concerning the probiotic potential characteristics, the evaluated strains showed good resistance to simulated gastric juice. In response to stress caused by acid, LAB use various mechanisms to overcome the damage, including maintaining the intracellular $\mathrm{pH}$ and cell membrane functionality and inducing stress-response proteins (Wu et al. 2014). These mechanisms vary both within species and according to exogenous conditions, including the growth media and incubation conditions (Madureira et al. 2011). The negative effect of bile on the viability of most lactobacilli was more accentuated than the effect of low $\mathrm{pH}$. The bile concentration in the human body usually ranges from $0.3 \%$ to $0.5 \%$ (García-Ruiz et al. 2014); therefore, probiotic bacteria must to be able to withstand these bile concentrations. Bile is a toxic component that damages the membrane by modifying its integrity and permeability. Additionally, bile disturbs the stability of macromolecules, including RNA, DNA and proteins, and may cause oxidative stress (Begley et al. 2006).

Generally, L. casei strains showed higher viability after successive exposures to gastric and intestinal conditions than L. delbrueckii subsp. bulgaricus. The survival of the selected strains, with the exception of $L$. delbrueckii subsp. bulgaricus SJRP149, was greater than the survival observed for the commercial strain used as a reference; similar results were obtained by Argyri et al. (2013). The good tolerance of Lactobacillus strains to gastric juice and bile is in accordance with the results reported in a previous study (Jensen et al. 2012). Nevertheless, no recovery in cell viability was observed for any of the strains in the subsequent treatment with enteric juice, which was in contrast to reports by other authors (Corsetti et al. 2008; Bautista-Gallego et al. 2013). This discrepancy most likely occurred because the strains did not have the ability to metabolize conjugated bile salts. The ability to hydrolyze bile salts is usually included as one of the criteria for the selection of strains with probiotic potential (Rodríguez et al. 2012). Nonetheless, BSH activity is rare among bacteria that have been isolated from environments with an absence of bile, such as the strains used in the present study. This finding is in agreement with other studies (Bautista-Gallego et al. 2013; Solieri et al. 2014).

Adhesion to intestinal epithelial cells is commonly included as an in vitro test to select probiotic strains. Although in vitro adhesion assays are useful for providing information on the differences among the strains being assessed, the results obtained from adhesion tests are different from the reality in vivo. The human GI tract has defense systems, resident 
flora, and bowel movements that may change the strain adhesion ability (Jensen et al. 2012). Moreover, different values for lactobacillus adhesion to Caco-2 cells have been reported, ranging from less than $1 \%$ to more than $70 \%$ (Jensen et al. 2012; Nikolic et al. 2012; Ramos et al. 2013; Tulumoğlu et al. 2014), possibly due to variation in the conditions used during the assay, such as the type of cell line, incubation time and number of probiotic cells added.

The presence of genes encoding adhesion, aggregation and colonization factors is desirable in LAB and can also indicate that the bacteria are able to adhere to the mucus layer (Jeronymo-Ceneviva et al. 2014). However, we did not find a correlation between the in vitro adhesion assay and the presence of adhesion genes because $L$. delbrueckii subsp. bulgaricus SJRP149 had the lowest ability to adhere to the Caco-2 cell model, despite presenting genes encoding adhesion, aggregation and colonization factors (except the $\operatorname{prg} B$ gene). Although in vitro tests are considered useful indicators of strain adhesion, they do not always reflect the ability of the bacteria to adhere to the mucus covering intestinal cells (Ramiah et al. 2007).

Antimicrobial activity was not detected in any of the neutralized CFSs, leading to the conclusion that no antimicrobial peptides or bacteriocin-like compounds were produced by these strains. This result is consistent with findings for other LAB strains, including Leuconostoc mesenteroides, Ln. pseudomesenteroides, L. plantarum, L. pentosus, L. paraplantarum, and L. paracasei subsp. paracasei (Argyri et al. 2013; Briggiler Marcó et al. 2014). Additionally, Ren et al. (2014) reported that most of the neutralized supernatants $(\mathrm{pH}$ 6.5) from lactobacilli and washed lactobacilli cells resuspended in fresh MRS broth lost their inhibitory activities against $E$. coli, $B$. cereus, and $S$. aureus when compared with fresh overnight lactobacilli strain cultures.

The production of $\beta$-galactosidase was investigated because the ability to produce this enzyme is an advantageous feature for probiotic strains. $\beta$-Galactosidase hydrolyzes lactose and is important for both consumers of dairy products who have lactose intolerance and for the production of dairy products.

Taking all of the results into account, L. fermentum SJRP30 and $L$. casei SJRP145 and SJRP146 are considered safe for future application as probiotics in co-culture with starter strains according to the tests suggested by FAO/WHO (ATCC 53103). Additionally, the selected strains possessed similar or superior probiotic potential characteristics compared to the reference strain $L$. rhamnosus GG. The promising results found for these strains suggest that additional in vitro or in vivo tests should be performed to verify the possible beneficial effects toward human health, including cholesterol-reducing ability, immunomodulatory effects and lowering the risk of GI diseases.
Acknowledgements This research was financially supported by the Sao Paulo Research Foundation (FAPESP, grants 2014/02131-8 and 2014/02132-4).

\section{Compliance with ethical standards}

Conflict of interest The authors declare that they have no conflict of interest. This article does not contain any studies with human participants or animals performed by any of the authors.

\section{References}

Aarestrup FM, Agerso Y, Gerner-Smidt P, Madsen M, Jensen LB (2000a) Comparison of antimicrobial resistance phenotypes and resistance genes in Enterococcus faecalis and Enterococcus faecium from humans in the community, broilers, and pigs in Denmark. Diagn Microbiol Infect Dis 37:127-137

Aarestrup FM, Agerso Y, Ahrens P, Jorgensen JCO, Madsen M, Jensen LB (2000b) Antimicrobial susceptibility and presence of resistance genes in staphylococci from poultry. Vet Microbiol 74:353-364

Abe F, Muto M, Yaeshima T, Iwatsuki K, Aihara H, Ohashi Y, Fujisawa T (2010) Safety evaluation of probiotic bifidobacteria by analysis of mucin degradation activity and translocation ability. Anaerobe 16: $131-136$

Adams CA (2010) The probiotic paradox: live and dead cells are biological response modifiers. Nutr Res Rev 23:37-46

Argyri AA, Zoumpopoulou G, Karatzas KAG, Nychas GJE, Panagou EZ, Tassou CC (2013) Selection of potential probiotic lactic acid bacteria from fermented olives by in vitro tests. Food Microbiol 33: 282-291

Bautista-Gallego J, Arroyo-López FN, Rantsiou K, Jiménez-Díaz R, Garrido-Fernández A, Cocolin L (2013) Screening of lactic acid bacteria isolated from fermented table olives with probiotic potential. Food Res Int 50:135-142

Begley M, Hill C, Gahan CGM (2006) Bile salt hydrolase activity in probiotics. Appl Environ Microbiol 72:1729-1738

Botta C, Langerholc T, Cencič A, Cocolin L (2014) In vitro selection and characterization of new probiotic candidates from table olive microbiota. PLoS One 9, e94457

Briggiler Marcó M, Zacarías MF, Vinderola G, Reinheimer JA, Quiberoni A (2014) Biological and probiotic characterisation of spontaneous phage-resistant mutants of Lactobacillus plantarum. Int Dairy J 39: 64-70

Bulajić S, Tambur Z, Opačić D, Miljković-Selimović B, Doder R, CenićMilošević D (2015) Characterization of antibiotic resistance phenotypes and resistance genes in Enterococcus spp. isolated from cheeses. Arch Biol Sci 67:139-146

Casado Muñoz MDC, Benomar N, Lerma LL, Gálvez A, Abriouel H (2014) Antibiotic resistance of Lactobacillus pentosus and Leuconostoc pseudomesenteroides isolated from naturallyfermented Aloreña table olives throughout fermentation process. Int J Food Microbiol 172:110-118

Charteris WP, Kelly PM, Morelli L, Collins JK (1998) Antibiotic susceptibility of potentially probiotic Lactobacillus species. J Food Prot 61: 1636-1643

Corsetti A, Caldini G, Mastrangelo M, Trotta F, Valmorri S, Cenci G (2008) Raw milk traditional Italian ewe cheeses as a source of Lactobacillus casei strains with acid-bile resistance and antigenotoxic properties. Int J Food Microbiol 125:330-335

Costa Y, Galimand M, Leclercq R, Duval J, Courvalin P (1993) Characterization of the chromosomal aac $\left(6^{\prime}\right)$-Ii genespecific for Enterococcus faecium. Antimicrob Agents Chemother 37:18961903 
Coton M, Romano A, Spano G, Ziegler K, Vetrana C, Desmarais C, Lonvaud-Funel A, Lucas P, Coton E (2010) Occurrence of biogenic amine-forming lactic acid bacteria in wine and cider. Food Microbiol 27:1078-1085

de Las Rivas B, Marcobal A, Munoz R (2005) Improved multiplex-PCR method for the simultaneous detection of food bacteria producing biogenic amines. FEMS Microbiol Lett 244:367-372

de Paula AT, Jeronymo-Ceneviva AB, Silva LF, Todorov SD, Franco BDGDM, Choiset Y, Haertlé T, Chobert J-M, Dousset X, Penna ALB (2014) Leuconostoc mesenteroides SJRP55: a bacteriocinogenic strain isolated from Brazilian water buffalo mozzarella cheese. Probiotics Antimicrob Proteins 6:186-197

de Paula AT, Jeronymo-Ceneviva AB, Silva LF, Todorov SD, Franco BDGM, Penna ALB (2015) Leuconostoc mesenteroides SJRP55: a potential probiotic strain isolated from Brazilian water buffalo mozzarella cheese. Ann Microbiol 65:899-910

Dutka-Malen S, Evers S, Courvalin P (1995) Detection of glycopeptide resistance genotypes and identification to the species level of clinically relevant enterococci by PCR. J Clin Microbiol 33:24-27

Eaton TJ, Gasson MJ (2001) Molecular screening of Enterococcus virulence determinants and potential for genetic exchange between food and medical isolates. Appl Environ Microbiol 67:1628-1635

EFSA (2012) Guidance on the assessment of bacterial susceptibility to antimicrobials of human and veterinary importance. EFSA Journal 10:10 pp. doi:10.2903/j.efsa.2012.2740. Available online: www. efsa.europa.eu/efsajournal. Accessed 28 July 2016

Egervärn M, Roos S, Lindmark H (2009) Identification and characterization of antibiotic resistance genes in Lactobacillus reuteri and Lactobacillus plantarum. J Appl Microbiol 107:1658-1668

FAO/WHO (2002) Guidelines for the evaluation of probiotics in food. Report of a Joint FAO/WHO working group on drafting guidelines for the evaluation of probiotics in food. Available at: ftp://ftp.fao. org/es/esn/food/wgreport2.pdf. Accessed 28 July 2016

Fernández MF, Boris S, Barbés C (2005) Safety evaluation of Lactobacillus delbrueckii subsp. lactis UO 004, a probiotic bacterium. Res Microbiol 156:154-160

Fortina MG, Ricci G, Borgo F, Manachini PL, Arends K, Schiwon K, Abajy MY, Grohmann E (2008) A survey on biotechnological potential and safety of the novel Enterococcus species of dairy origin, E. italicus. Int J Food Microbiol 123:204-211

García-Ruiz A, González de Llano D, Esteban-Fernández A, Requena T, Bartolomé B, Moreno-Arribas MV (2014) Assessment of probiotic properties in lactic acid bacteria isolated from wine. Food Microbiol 44:220-225

Gevers D, Danielsen M, Huys G, Swings J (2003) Molecular characterization of tet $(M)$ genes in Lactobacillus isolates from different types of fermented dry sausage. Appl Environ Microbiol 69:1270-1275

Guarner F, Malagelada JR (2003) Gut flora in health and disease. Lancet 360:512-519

Hill C, Guarner F, Reid G, Gibson GR, Merenstein DJ, Pot B, Morelli L, Canani RB, Flint HJ, Salminen S, Calder PC, Sanders ME (2014) Expert consensus document: the International Scientific Association for Probiotics and Prebiotics consensus statement on the scope and appropriate use of the term probiotic. Nat Rev Gastroenterol Hepatol 11:506-514

Ilavenil S, Vijayakumar M, Kim DH, Valan Arasu M, Park HS, Ravikumar S, Choi KC (2015) Assessment of probiotic, antifungal and cholesterol lowering properties of Pediococcus pentosaceus KCC-23 isolated from Italian ryegrass. J Sci Food Agric 96:593601

Jaimee G, Halami PM (2016) High level aminoglycoside resistance in Enterococcus, Pediococcus and Lactobacillus species from farm animals and commercial meat products. Ann Microbiol 66:101-110

Jensen H, Grimmer S, Naterstad K, Axelsson L (2012) In vitro testing of commercial and potential probiotic lactic acid bacteria. Int J Food Microbiol 153:216-222
Jeronymo-Ceneviva AB, de Paula AT, Silva LF, Todorov SD, Franco BDGM, Penna ALB (2014) Probiotic properties of lactic acid bacteria isolated from water-buffalo mozzarella cheese. Probiotics Antimicrob Proteins 6:141-156

Kastner S, Perreten V, Bleuler H, Hugenschmidt G, Lacroix C, Meile L (2006) Antibiotic susceptibility patterns and resistance genes of starter cultures and probiotic bacteria used in food. Syst Appl Microbiol 29:145-155

Klare I, Konstabel C, Werner G, Huys G, Vankerckhoven V, Kahlmeter G, Hildebrandt B, Müller-Bertling S, Witte W, Goossens H (2007) Antimicrobial susceptibilities of Lactobacillus, Pediococcus and Lactococcus human isolates and cultures intended for probiotic or nutritional use. J Antimicrob Chemother 59:900-912

Klein G, Hallmann C, Casas IA, Abad J, Louwers J, Reuter G (2000) Exclusion of vanA, vanB and vanC type glycopeptide resistance in strains of Lactobacillus reuteri and Lactobacillus rhamnosus used as probiotics by polymerase chain reaction and hybridization methods. J Appl Microbiol 89:815-824

Kochan P, Chmielarczyk A, Szymaniak L, Brykczynski M, Galant K, Zych A, Pakosz K, Giedrys-Kalemba S, Lenouvel E, Heczko PB (2011) Lactobacillus rhamnosus administration causes sepsis in a cardiosurgical patient - is the time right to revise probiotic safety guidelines? Clin Microbiol Infect 17:1589-1592

Lee KW, Park JY, Sa HD, Jeong JH, Jin DE, Heo HJ, Kim JH (2014) Probiotic properties of Pediococcus strains isolated from jeotgals, salted and fermented Korean sea-food. Anaerobe 28:199-206

Liong MT (2008) Safety of probiotics: translocation and infection. Nutr Rev 66:192-202

Lopes MDFS, Simões AP, Tenreiro R, Marques JJF, Crespo MTB (2006) Activity and expression of a virulence factor, gelatinase, in dairy enterococci. Int J Food Microbiol 112:208-214

Madureira AR, Amorim M, Gomes AM, Pintado ME, Malcata FX (2011) Protective effect of whey cheese matrix on probiotic strains exposed to simulated gastrointestinal conditions. Food Res Int 44:465-470

Manson JM, Keis S, Smith JMB, Cook GM (2004) Acquired bacitracin resistance in Enterococcus faecalis is mediated by an ABC transporter and a novel regulatory protein, BcrR. Antimicrob Agents Chemother 48:3743-3748

Martín-Platero AM, Valdivia E, Maqueda M, Martínez-Bueno M (2009) Characterization and safety evaluation of enterococci isolated from Spanish goats' milk cheeses. Int J Food Microbiol 132:24-32

Miele A, Bandera M, Goldstein BP (1995) Use of primers selective for vancomycin resistance genes to determine van genotype in enterococci and to study gene organization in vanA isolates. Antimicrob Agents Chemother 39:1772-1778

Mishra V, Shah C, Mokashe N, Chavan R, Yadav H, Prajapati J (2015) Probiotics as potential antioxidants: a systematic review. J Agric Food Chem 63:3615-3626

Monteagudo-Mera A, Rodríguez-Aparicio L, Rúa J, Martínez-Blanco H, Navasa N, García-Armesto MR, Ferrero MÁ (2012) In vitro evaluation of physiological probiotic properties of different lactic acid bacteria strains of dairy and human origin. J Funct Foods 4:531-541

Morandi S, Silvetti T, Miranda Lopez JM, Brasca M (2015) Antimicrobial activity, antibiotic resistance and the safety of lactic acid bacteria in raw milk valtellina Casera cheese. J Food Saf 35: 193-205

Nikolic M, López P, Strahinic I, Suárez A, Kojic M, Fernández-García M, Topisirovic L, Golic N, Ruas-Madiedo P (2012) Characterisation of the exopolysaccharide (EPS)-producing Lactobacillus paraplantarum BGCG11 and its non-EPS producing derivative strains as potential probiotics. Int J Food Microbiol 158:155-162

Oh YJ, Jung DS (2015) Evaluation of probiotic properties of Lactobacillus and Pediococcus strains isolated from Omegisool, a traditionally fermented millet alcoholic beverage in Korea. LWT Food Sci Technol 63:437-444 
Peres CM, Alves M, Hernandez-Mendoza A, Moreira L, Silva S, Bronze MR, Vilas-Boas L, Peres C, Malcata FX (2014) Novel isolates of lactobacilli from fermented Portuguese olive as potential probiotics. LWT Food Sci Technol 59:234-246

Perin LM, Miranda RO, Todorov SD, Franco BDGDM, Nero LA (2014) Virulence, antibiotic resistance and biogenic amines of bacteriocinogenic lactococci and enterococci isolated from goat milk. Int J Food Microbiol 185:121-126

Pieniz S, Andreazza R, Anghinoni T, Camargo F, Brandelli A (2014) Probiotic potential, antimicrobial and antioxidant activities of Enterococcus durans strain LAB18s. Food Control 37:251-256

Ramiah K, van Reenen CA, Dicks LMT (2007) Expression of the mucus adhesion genes $M u b$ and MapA, adhesion-like factor EF-Tu and bacteriocin gene plaA of Lactobacillus plantarum 423, monitored with real-time PCR. Int J Food Microbiol 116:405-409

Ramos CL, Thorsen L, Schwan RF, Jespersen L (2013) Strain-specific probiotics properties of Lactobacillus fermentum, Lactobacillus plantarum and Lactobacillus brevis isolates from Brazilian food products. Food Microbiol 36:22-29

Ren D, Li C, Qin Y, Yin R, Du S, Ye F, Liu C, Liu H, Wang M, Li Y, Sun Y, Li X, Tian M, Jin N (2014) In vitro evaluation of the probiotic and functional potential of Lactobacillus strains isolated from fermented food and human intestine. Anaerobe 30:1-10

Rodríguez E, Arqués JL, Rodríguez R, Peirotén Á, Landete JM, Medina M (2012) Antimicrobial properties of probiotic strains isolated from breast-fed infants. J Funct Foods 4:542-551

Ryu EH, Chang HC (2013) In vitro study of potentially probiotic lactic acid bacteria strains isolated from kimchi. Ann Microbiol 63:13871395

Shah NP (2000) Probiotic bacteria: selective enumeration and survival in dairy foods. J Dairy Sci 83:894-907

Sharma M, Devi M (2014) Probiotics: a comprehensive approach toward health foods. Crit Rev Food Sci Nutr 54:537-552

Sharma P, Tomar SK, Sangwan V, Goswami P, Singh R (2015) Antibiotic resistance of Lactobacillus sp. isolated from commercial probiotic preparations. J Food Saf 36:38-51

Silva LF (2015) Diversidade e evolução da microbiota lática autóctone em queijo Muçarela de búfala e aplicação tecnológica dos isolados [Diversity and evolution of authoctonous lactic microbiota in water buffalo Mozzarella cheese and technological application of isolates]. Thesis, Sao Paulo State University

Silva LF, Casella T, Gomes ES, Nogueira MCL, De Dea LJ, Penna ALB (2015) Diversity of lactic acid bacteria islated from Brazilian water buffalo mozzarella cheese. J Food Sci 80:M411-M417
Solieri L, Bianchi A, Mottolese G, Lemmetti F, Giudici P (2014) Tailoring the probiotic potential of non-starter Lactobacillus strains from ripened Parmigiano Reggiano cheese by in vitro screening and principal component analysis. Food Microbiol 38:240-249

Sutcliffe J, Grebe T, Tait-kamradt A, Wondrack L (1996) Detection of erythromycin-resistant determinants by PCR. Antimicrob Agents Chemother 40:2562-2566

Tulini FL, Winkelströter LK, De Martinis ECP (2013) Identification and evaluation of the probiotic potential of Lactobacillus paraplantarum FT259, a bacteriocinogenic strain isolated from Brazilian semi-hard artisanal cheese. Anaerobe 22:57-63

Tulumoğlu Ş, Kaya Hİ, Şimşek Ö (2014) Probiotic characteristics of Lactobacillus fermentum strains isolated from tulum cheese. Anaerobe 30:120-125

Tynkkynen S, Singh KV, Varmanen P (1998) Vancomycin resistance factor of Lactobacillus rhamnosus GG in relation to enterococcal vancomycin resistance (van) genes. Int J Food Microbiol 41:195204

Vankerckhoven V, Autgaerden TV, Vael C, Lammens C, Chapelle S, Rossi R, Jabes D, Goossens H (2004) Development of a multiplex PCR for the detection of asal, gelE, cylA, esp, and hyl genes in Enterococci and survey for virulence determinants among European hospital isolates of Enterococcus faecium. J Clin Microbiol 42:4473-4479

Vijayakumar M, Ilavenil S, Kim DH, Arasu MV, Priya K, Choi KC (2015) In-vitro assessment of the probiotic potential of Lactobacillus plantarum KCC-24 isolated from Italian rye-grass (Lolium multiflorum) forage. Anaerobe 32:90-97

Wu C, He G, Zhang J (2014) Physiological and proteomic analysis of Lactobacillus casei in response to acid adaptation. J Ind Microbiol Biotechnol 41:1533-1540

Zbinden A, Zbinden R, Berger C, Arlettaz R (2015) Case series of Bifidobacterium longum bacteremia in three preterm infants on probiotic therapy. Neonatology 107:56-59

Zhou JS, Gopal PK, Gill HS (2001) Potential probiotic lactic acid bacteria Lactobacillus rhamnosus (HN001), Lactobacillus acidophilus (HN017) and Bifidobacterium lactis (HN019) do not degrade gastric mucin in vitro. Int J Food Microbiol 63:81-90

Zhou N, Zhang JX, Fan MT, Wang J, Guo G, Wei XY (2012) Antibiotic resistance of lactic acid bacteria isolated from Chinese yogurts. J Dairy Sci 95:4775-4783

Zonenschain D, Rebecchi A, Morelli L (2009) Erythromycin- and tetracycline-resistant lactobacilli in Italian fermented dry sausages. J Appl Microbiol 107:1559-1568 